IZA DP No. 5142

Ethnic Fragmentation, Conflict, Displaced Persons and Human Trafficking: An Empirical Analysis

Randall K. Q. Akee

Arnab K. Basu

Nancy H. Chau

Melanie Khamis

August 2010 


\title{
Ethnic Fragmentation, Conflict, Displaced Persons and Human Trafficking: An Empirical Analysis
}

Randall K. Q. Akee

Tufts University and IZA

\author{
Arnab K. Basu \\ College of William and Mary, ZEF and IZA \\ Nancy H. Chau \\ Cornell University, ZEF and IZA \\ Melanie Khamis \\ IZA \\ Discussion Paper No. 5142 \\ August 2010
}

IZA

P.O. Box 7240

53072 Bonn

Germany

Phone: +49-228-3894-0

Fax: +49-228-3894-180

E-mail: iza@iza.org

Any opinions expressed here are those of the author(s) and not those of IZA. Research published in this series may include views on policy, but the institute itself takes no institutional policy positions.

The Institute for the Study of Labor (IZA) in Bonn is a local and virtual international research center and a place of communication between science, politics and business. IZA is an independent nonprofit organization supported by Deutsche Post Foundation. The center is associated with the University of Bonn and offers a stimulating research environment through its international network, workshops and conferences, data service, project support, research visits and doctoral program. IZA engages in (i) original and internationally competitive research in all fields of labor economics, (ii) development of policy concepts, and (iii) dissemination of research results and concepts to the interested public.

IZA Discussion Papers often represent preliminary work and are circulated to encourage discussion. Citation of such a paper should account for its provisional character. A revised version may be available directly from the author. 
IZA Discussion Paper No. 5142

August 2010

\section{ABSTRACT \\ Ethnic Fragmentation, Conflict, Displaced Persons and Human Trafficking: An Empirical Analysis ${ }^{*}$}

Ethnic conflicts and their links to international human trafficking have recently received a surge in international attention. It appears that ethnic conflicts exacerbate the internal displacement of individuals from networks of family and community, and their access to economic and social safety nets. These same individuals are then vulnerable to being trafficked by the hopes of better economic prospects elsewhere. In this paper, we empirically examine this link between ethnic fragmentation, conflicts, internally displaced persons (IDPs), refugees and international trafficking, making use of a novel dataset of international trafficking. We conduct a direct estimation, which highlights the ultimate impact of ethnic fragmentation and conflict on international trafficking through internal and international displacements.

JEL Classification: R23, D74, O11, Z12

Keywords: ethnic fragmentation, conflict, displaced persons, human trafficking

Corresponding author:

Melanie Khamis

IZA

P.O. Box 7240

53072 Bonn

Germany

E-mail: khamis@iza.org

\footnotetext{
* Financial support from the Alexander von Humboldt Foundation (Transcoop Grant) is gratefully acknowledged. The usual disclaimer applies.
} 


\section{Introduction}

The link between ethnic conflicts and international trafficking is an issue that has recently received a surge in international attention. The main argument is that internal conflicts encourage the internal displacement of individuals from networks of family and community, and their access to economic and social safety nets. These same individuals are particularly vulnerable to being trafficked, by the hopes of better economic prospects elsewhere. In this paper, we take this link between ethnic fragmentation, conflicts, internal and internally displaced people from a country and international trafficking to the data for the first time, making use of a novel dataset of international trafficking.

While there is an extensive empirical literature linking ethnic fragmentation to conflict, and an equally extensive literature linking conflict to internally displaced persons (IDPs) and international refugees, scant empirical attention has been accorded either to the link between IDPs / refugees and international human trafficking or to the link between ethnic fragmentation, conflict, IDPs/refugees and trafficking. Given that the factors that force migration within and across international borders are similar to the ones that are at play in the trafficking context, it would seem natural explore the link. However, before we look into the existing literature in this area, it is necessary to unravel the causal link from ethnic fragmentation to conflict since the issue of IDPs and refugees is crucially linked to the incidence and intensity of conflict.

Is ethnic fragmentation a cause for conflict within nations? The answer is not clear. Prior to 1980, only fifteen countries could be identified as homogenous with the two Koreas, Portugal and Japan leading this select group (Connor, 1983; Lee et.al, 2002). Correspondingly over the 1950-1989 period, Gurr (1993) finds that non-violent protests by ethnic minority groups increased by $230 \%$, violent protests rose by $430 \%$ and rebellions increased by $360 \%$. Since the end of the Cold War the fraction of countries that could be characterized as ethnically homogenous has fallen further with the break-up of the ex-Soviet Union, and as Reilly (2000) reports, of the 110 major conflicts globally over this time period, 103 were intra-state in nature. A primary cause of ethnic conflict across nations arises out of interactions between ethnic groups and government, through either (i) government coercion in response to the threat of dissent and rebellion from ethnic groups; (ii) ethnic groups having a mobilization advantage and are therefore more likely to engage in protest or (iii) democratization, which ties a government's hands with respect to coercion thereby allowing ethnic groups the leeway to mobilize and protest (Lee st.al, 2002). Lindstrom (1996) in fact finds support for the hypothesis that ethnic fragmentation is positively correlated with conflict, in consonance with the theory that ethnic fragmentation is closely related with mobilization for dissent.

The literature on the link between ethnic fragmentation and conflict can be further classified into two branches - democratic and non-democratic societies. In democratic societies, the main cause of conflict is increasing inter ethnic-group economic inequality caused by (i) economic policies instituted by the government, (ii) the classic tragedy of the commons case wherein one ethnic group fails to internalize the costs that their choices impart on other ethnic groups, (iii) bureaucratic corruption, (iv) the 'resource curse' where the rents from natural resource extraction accrue only to a minority group within a country and finally (v) political transitions. In so far as issues (i), (ii) and (iii) above are concerned, Horowitz (1985) notes that individuals often derive 
enjoyment from seeing benefits accrue to members of their group (be it class- or ethnic-based) even when they themselves do not directly share in those benefits. Empirically, Alesina, Baqir, and Easterly (1999) find that U.S. cities characterized by higher levels of ethnic fragmentation and economic inequality exhibit higher overall levels of both government spending and debt while at the same time devote lower shares of total spending towards investment in public goods. This suggests that cities with higher ethnic fragmentation and inequality spend more on patronage for conflicting special interest groups. Thus, any economic or social policy that is deemed to confer additional benefits purely to a particular ethnic group can be a cause for dissent and conflict. An additional cause of ethnic conflict stems from the inability of international, national and regional powers to adequately provide security for minority groups. Finally for nondemocratic countries, ethnic conflict is more often than not linked to repression of ethnic groups by military dictatorships, and frequent struggles for power through coups and rebellions.

However, it can be argued that that ethnic fragmentation (or the share of an ethnic group in the total population) within a country does not necessarily imply dissent even in the face of perceived unjust economic and social policies --- what matters probably more is the relative strength of an ethnic group vis-à-vis others within a country. While the theories linking ethnic fragmentation and conflict are wide-ranging and still debated, the link between conflict (ethnic, religious, ideological, or otherwise) and the problem of IDPs and refugees is far more clear-cut. IDPs and international refugees constitute the spectrum of people fleeing conflict, post-conflict returnees, people displaced by environmental and natural disasters, people displaced by development projects like large dams. Spiegel (2004) notes that by the end of 2002, there were approximately 40 million displaced people globally with 15 million refugees (UNHCR, 2003), and 25 million IDPs (Global IDP Project, 2003). Moreover, IDPs and refugees are either the poorest or those stripped of resources by stronger groups (Mani, 2005). Displacement leads to the breakdown of social structures and informal and formal insurance mechanisms along with a disruption of employment, healthcare, education and financial services making IDPs and refugees a vulnerable group. Specially affected amongst the IDPs and refugees are women and children who suffer the most in terms of food insecurity, hunger and unequal distribution of material goods. As a result, women and children are the most at risk of exploitation and abuse, including coercion into transactional sex for survival. Indeed, Mani (2005) points to the case of Sierra Leone where provisions were allocated to women refugees in exchange of sexual favors with the threat of violence.

While studies do document that women and children are the most vulnerable amongst IDPs and refugees it does not necessarily imply that this group are also victims of trafficking across international borders. Our hypothesis that conflict-prone countries with a high number of IDPs and source countries for refugees may also turn out to be the source country for trafficked victims is based on two sets of information delineated below. First, data on the countries of origin for asylum seekers into North America, Western Europe and Australia closely mirror the country of origin of trafficked victims into these regions. Second, case studies based on two ethnically fragmented and conflict prone countries --- Nigeria and Nepal --- show that the IDPs and refugees, specially, women and children, are indeed victims of trafficking.

Data on international refugees and asylum seekers from the United Nations High Commissioner for Refugees (UNHCR) show that the global refugee population grew from 2.4 million in 1975 
14.9 million in 1990. After reaching a peak at the end of the Cold War the global refugee population had declined to 12.1 million in 2000 (UNHCR 1995; UNHCR 2000, Castles and Loughna, 2003). Refugees came mainly from countries affected by civil conflict with the top ten countries of origin in 1999 being Afghanistan (2.6 million), Iraq (572,000), Burundi $(524,000)$, Sierra Leone $(487,000)$, Sudan $(468,000)$, Somalia $(452,000)$, Bosnia $(383,000)$, Angola $(351,000)$, Eritrea $(346,000)$ and Croatia $(340,000)$.

Next we look at the top ten countries of origin for asylum-seekers entering USA, Canada, Western Europe and Australia from 1990 to 2001 According to Castles and Loughna (2003), the countries of origin of the top ten asylum seekers into the USA over the 1990-2001 period were El Salvador $(223,887)$, Guatemala $(178,047)$, Mexico $(66,338)$, China $(60,926)$, Haiti $(51,308)$, Nicaragua $(34,411)$, India $(30,985)$, Russia $(20,913)$, Pakistan $(16,700)$ and Cuba $(16,600)$ with the share of the top ten being $70 \%$ of the total number of asylum seekers over this time period. Notable here is the fact that the top three countries in question (El Salvador, Guatemala and Mexico) are also ethnically fragmented and conflict ridden countries with a significant number of IDPs and refugees from neighboring conflict prone countries like Nicaragua and Honduras. A similar pattern for asylum seekers can be also observed for Canada with the top ten countries of origin for asylum seekers being Sri Lanka $(40,009)$, Somalia $(21,120)$, Pakistan $(18,680)$, China $(17,651)$, Iran $(15,590)$, India $(14,106)$, Mexico $(8,940)$, Hungary $(8,915)$, Israel $(8,527)$, DR Congo $(8,229)$ with the share of the top ten being $46 \%$ of the total number of asylum seekers over the 1990-2001 time period. Once again, the top three countries of origin of asylum seekers into Canada (Sri Lanka, Somalia and Pakistan) are ethnically fragmented and conflict ridden countries. Moreover, Somalia is also host to refugees fleeing conflict and food insecurity from Ethiopia and Sudan, Pakistan being host to Afghan refugees while DR Congo hosts refugees from Rwanda. Coincidentally, data from 2002 also show that the USA and Canada are also host countries of trafficked victims from Mexico, Guatemala and El Salvador (Akee et.al, 2009).

For Western Europe the top ten countries of origin of asylum-seekers over the 1990-2001 time period were FR Yugoslavia $(935,973)$, Romania $(412,326)$, Turkey $(392,867)$, Iraq $(272,918)$, Afghanistan $(192,581)$, Bosnia \& Herzegovina $(184,005)$, Sri Lanka $(169,666)$, Iran $(143,651)$, Somalia $(142,148)$, DR Congo $(123,441)$ with the top ten share of the total number of asylum seekers over the 1990-2001 time period being 59\%. All countries in the top ten list are ethnically fragmented with either prolonged periods of civil conflict or in political transition. Similar to the USA and Canada, Western European countries are also host to trafficked victims from the conflict prone countries of Eastern Europe (Bosnia \& Herzegovina, Georgia and Kyrgyzstan, amongst others) and Africa (Somalia, Nigeria Sierra Leone and Mozambique, amongst others). Finally, for Australia the top ten countries of origin of asylum-seekers between 1996-2001 were Indonesia (7,529), China (6,649), Iraq (5,378), Philippines (4,665), Afghanistan $(4,241)$, Sri Lanka $(4,025)$, India $(2,873)$, Fiji $(2,134)$, Iran $(1,910)$, Thailand $(1,263)$ with the top ten share of the total number of asylum seekers over this time period being $65 \%$. Needless to say, Indonesia and Sri Lanka have been plagued by prolonged ethnic conflicts, and Australia is also a host country of trafficked victims from Indonesia, Thailand and Cambodia, amongst others.

However, one cannot draw a definite conclusion that the pattern of asylum seekers and trafficked victims are positively correlated from a casual look at the data. After all, asylum migration (which is legal) and trafficking (illegal) are distinctly different channels through which people 
move or are moved across borders. While it might well be that trafficked victims could be either be misled with the hope of gaining asylum in host countries by middlemen or that trafficking becomes the next best alternative in response to stringent immigration laws in host countries, the dynamics of legal migration is distinct from that of illicit migration like trafficking where migrants face different levels of risk, vulnerability and employment outcomes in the host countries. Suffice to say, that some of the push factors behind asylum migration, namely (i) repression of minorities or ethnic conflict, (ii) civil war, (iii) high numbers of internally displaced persons (IDPs) relative to total population, (iv) poverty as reflected in low per capita income, (v) low position on the Human Development Index (HDI), (vi) low life expectancy, (vii) high population density and (viii) high adult literacy rate; mirror closely the push factors that induce trafficking, namely (i) poverty, (ii) lack of educational opportunities and (iii) armed conflict (Castles and Loughna, 2003; Akee et.al, 2009). To get a better sense of what drives the positive correlation between conflict, IDPs/refugees and trafficked victims we look at two case studies, from Nigeria (ethnic, religious and resource conflict) and Nepal (ideological conflict).

Our data on trafficking suggests that Nigeria is hub country of trafficked victims (women and children). In other words, it is both a source as well as a host country for trafficking. Victims are trafficked out of Nigeria to Western Europe, South Africa and Gulf countries while trafficked victims enter Nigeria from West African countries like Liberia, Sierra Leone, Mali, Cameroon and Côte d'Ivoire (Akee et.al. 2009). Recent evidence suggests that traffickers in Kano state exploited the annual pilgrimage to Mecca to traffic children, men and women for different exploitative purposes like prostitution, begging and domestic work. Moreover, and historically, women are recruited in the Edo state and are trafficked into Italy, Netherlands, Spain and other countries to work as prostitutes (de Haas, 2006; Ehindero et al. 2006; and Carling, 2005). Concurrently, Nigerians are the fifth largest group of asylum seekers in Western European countries while at the same time host a large number of refugees and asylum seekers - majority of whom are from Sierra Leone, Chad, Liberia, DR Congo, Sudan (Darfur), Somalia, Côte d'Ivoire, Niger and Cameroon (de Haas, 2006). There are also two major issues that lead to a high degree of labor mobility within Nigeria: conflict and the institution of 'foster' children. Religious and ethnic conflicts (in Plateau and Kano states in 2004 and in Benue state in 2001 respectively) as well as conflicts over crude oil mining and refining in the Delta area has led to Nigeria having the highest number of IDPs in West Africa --- estimated to be as high as 1.2 million at the end of the 1990s (de Haas, 2006). Further, child fostering is a well-established practice in Nigeria in which poor rural families send their children to family members in urban areas so that they can get better education and employment opportunities. However, several of these children end up working as child laborers. Thus, IDPs, refugees into Nigeria, and foster children combine to constitute a vulnerable group susceptible to traffickers (de Haas, 2006).

Nepal, unlike Nigeria which is a hub country of trafficking, is a source country for trafficked victims primarily into India. Further, armed conflict between Maoist guerillas and the ex-Royal Nepalese Army has led to an estimated displacement of 200,000 people both internally and across the border (Internal Displacement Monitoring Centre, 2006; Bharadwaj et. al 2007). However, a high percentage of the displaced population in Nepal constitute women and young girls, who in addition to lacking access to basic needs are vulnerable to trafficking (Tamang 2009). 
With the above background in place, we empirically test whether there is indeed a correlation between ethnic fragmentation, conflict, IDPs/refugees and trafficking. In what follows, we use religious and linguistic fragmentation, in addition to ethnic fragmentation and different measures of conflict to understand which type(s) of fragmentation and conflict(s) are most significant in explaining the presence of IDPs within and refugees from a country, as well as the factors that increase the incidence of trafficking between countries.

\section{Data}

For this research on human trafficking and the relationship between internally displaced persons and refugees, ethnic fragmentation and conflict, data were collected from various sources described below. A description of these specific variables can be found in Table 1, which contains all the variables employed in our estimations. Table 2 shows the basic descriptive statistics of the dataset at the country level for the main explanatory variables of interest: fragmentation, IDPs/refugees and conflict measures. Finally, Table 3 provides the descriptive statistics of the estimation sample.

Data on the reported incidence of trafficking was compiled from the country-by-country descriptive accounts of the Trafficking in Persons (TIP) report (US Department of State 2003). A country is designated as a "Host" country for trafficked victims only if 100 cases were reported in the past year. Country host-source pairs of trafficking are coded from these reports for the year 2002. The number of internally displaced persons (IDPs) and IDP-like situations are data collected by United Nations High Commissioner for Refugees (UNHCR), the United Nations Refugee agency and we use their data for the period 1993-2001. We use data on the number of refugees from origin from UNHCR to generate an average for the years 1993 to 2001. The incidence of refugees from a source country along with IDPs within a source country is then combined in a single IDPs/refugees dummy variable for a source country. Fragmentation measures were taken from Alesina et al. (2003), where fragmentation (ethnic, religious or linguistic) is defined as $F_{R A C T_{j}}=1-\sum_{i=1}^{N} S_{i j}^{2}$ where $S_{i j}$ is the share of group i, $(\mathrm{i}=1 \ldots \mathrm{N})$ in country $\mathrm{j}$. Ethnic, religious and language fractionalization cover a larger range of countries and various aspects of fragmentation, which we employ here to understand the impact on international trafficking. As Alesina et al. (2003) discuss, these three indices are correlated and we will employ them separately in our estimations. The ethnic fragmentation measures were available for various years until 2001, while language and religious fragmentation were measured for the year 2001.

Conflict measures were collected from the Uppsala Conflict Data Program (UCDP)/ International Peace Research Institute, Oslo (PRIO) Armed Conflict Dataset (2009) and Gleditsch et al. (2002) for the period 1946 to 2001. We employ an average of these measures over this time period in our estimations. We account for various measures of conflict in our estimations. First, we use two measures that capture the intensity of conflict: (i) the cumulative intensity dummy takes into account the history of the conflict. It takes the value 0 if the conflict has resulted in less than 1,000 battle-related deaths and 1 otherwise and (ii) the level intensity of conflict is measured by distinguishing between either a minor conflict or a war (where a minor conflict has more than 25 battle-related deaths per year for every year in the period while a war is defined as one where are more than 1000 battle-related deaths per year for every year in the 
period). Second, we use a count measure of the number of conflicts within a country. Third and finally, we use a more complex measure that differentiates between the types of conflict into four categories.

- The type 1 variable takes the value $0.1,2,3$ respectively and distinguishes between no conflict, minor armed conflict, intermediate armed conflict and war at the extra-state level (extra-state conflict is a conflict over a territory between a government and one or more opposition groups, where the territory is a colony of the government. Also, a minor conflict is one where more than 25 battle-related deaths per year for every year in the period has been reported, an intermediate conflict is one where more than 25 battlerelated deaths per year (but less than 1000) with a total conflict history of more than 1000 battle-related reported deaths while a war is where more than 1000 battle-related deaths has been reported per year for every year in the period).

- The type 2 variable takes the value $0,1,2$ and 3 respectively for no conflict, minor armed conflict, intermediate armed conflict and war at the interstate level (interstate conflict is a conflict between two or more countries and governments ).

- The type 3 variable takes the value $0,1,2$ and 3 respectively and separates the conflict levels at the internal level (internal conflict is conflict within a country between a government and one or more opposition groups, with no interference from other countries).

- The type 4 variable distinguishes whether the conflict/war was an internationalized internal one or not, and then at what level (minor armed conflict, intermediate armed conflict or war. An Internationalized internal conflict is similar to internal conflict, but where the government, the opposition or both sides receive support from other governments).

In addition to the data on trafficking, ethnic/religious/linguistic fragmentation, IDPs/refugees, and conflict we use the following as control variables. First, we use Gross Domestic Product (GDP) for the host and source countries as the refugees and trafficking literature finds that relatively poorer countries are source countries while richer countries are the host for international refugees and trafficked victims. Second, we use an indicator variable - landlocked -- that takes on a value of 1 if a country (trafficking host or source) is landlocked and 0 otherwise. Third, we use a common border and common region dummies for host and source countries of trafficking. These last three variables (landlocked, common border and common region) are meant to account for the ease with which both refugees and trafficked victims can move between source and host countries, and whether the incidence of refugee migration and trafficking are more likely to be observed within a common region and between neighboring countries. The GDP and the landlocked indicator were obtained from the World Bank Development Indicators for the year 2000. The common border and common region measures were self collected and coded from the Central Intelligence Agency's World Factbook (2001).

Frequently cited in the trafficking literature is the role of (or the lack thereof) legislation surrounding prostitution activities and the enforcement of these laws since most trafficked 
victims are women and children who are forced into exploitative sexual activities. We use data on legislation surrounding prostitution activities (pimping, pandering, brothels) from the Protection Project Country Report (2002) for the year 2001 and the 'rule of law' index from Kaufmann, Kraay and Zoido-Lobaton (1999 a \& b) to proxy for corruption and governance for all countries in our dataset. The "rule of law" indicator is a composite index of (i) voice (e.g., freedom of press and the freedom to associate) and accountability; (ii) political stability/lack of violence; (iii) government effectiveness; (iv) regulatory framework; (v) rule of law; and (vi) control of corruption. The index ranges from -3 (worst) to +3 (best).

The reason for using legislation surrounding prostitution as a variable across host and source countries of trafficking stems from the following argument. First, stricter laws surrounding prostitution in source countries makes it an illegal activity in these countries and one would expect that prostitution commands a higher return in an illegal market rather than a legal one to compensate for the risk of getting caught and punished. However, a higher return from illegal prostitution in the source country allows traffickers and middlemen to extract a higher price from buyers of trafficked victims in the host countries if these earnings from illegal prostitution in the source country constitute the 'reservation' price at which traffickers sell their victims in the host country. Similarly, a ban on prostitution in the host countries of trafficking would imply that prostitutes in this illegal activity would earn a higher return than otherwise. Again, this allows for a higher price to be extracted for trafficked victims by the middlemen who sell these victims to the host country buyer. As we show in Akee et. al (2010), a ban on prostitution in either a source or a host country can tilt the incentive in favor of traffickers to move victims across borders for the purpose of prostitution.

\section{Empirical Methodology and Results}

To determine the link between ethnic conflicts and international trafficking, we estimate the direct effect of ethnic fragmentation, various types of external and internal conflicts, presence of IDPs/refugees in a source country on the incidence of trafficking between countries. This model is presented below:

$$
\begin{aligned}
\text { trafficking }_{i j}= & \alpha_{1}+\beta_{1} \text { frag }_{i}+\beta_{2} \text { frag }_{i}^{2}+\beta_{3} \text { refidp }_{i}+\beta_{4} \text { conflict }_{i \bar{i}}+\beta_{5} \text { Controls }_{i}+ \\
& \beta_{6} \text { Controls }_{j}+\varepsilon_{i \bar{j}}
\end{aligned}
$$

where trafficking is the binary dependent variable for the incidence of trafficking from country $i$ to country $j$ (source $i$ to host $j$ ). This variable takes the value 1 if an incidence of trafficking from country $i$ to country $j$ is reported and 0 otherwise.

The variable frag measures fragmentation in the source country of trafficking. It is measured continuously from 0 to 1 while $f r a g^{2}$ is the squared value of the fragmentation variable. Three measures, ethnic, religious and language fractionalization, are included in turn in the different regression specifications. The dummy variable refidp indicates the presence of refugees as well as internally displaced persons in the source country. The variable conflict captures the various measures of conflict in a source country that we have discussed earlier, and we include these 
various measures in separate regression specifications for each fragmentation measure (ethnic, religious and linguistic). The control variables for the host and source countries include GDP, prohibition of prostitution, rule of law index, common border, common region and the landlocked dummy.

We report the results related to the direct impact of ethnic/religious/linguistic fragmentation, conflict and IDPs/refugees on the dummy variable capturing the incidence of trafficking between two countries - host and source. Tables 4.1, 4.2 and 4.3 reports the results, with Table 4.1 being specific to the ethnic fragmentation variable while Tables 4.2 and 4.3 specific to the religious and linguistic fragmentation variables respectively.

From Table 4.1, we start with those results that are robust to all the conflict measures used in our regression (cumulative intensity, level intensity, count, Types 1-4 and location). We find that a lower GDP for source countries and a higher GDP for host countries increases the likelihood of a source-host match for trafficking. This is in consonance with both earlier empirical studies (Akee et.al. 2010) and the literature based on government reports and victim surveys that the countries of origin for trafficked victims are relatively poorer as compared to the destination countries. The coefficient on common border and common region are positive and significant for both the host and source countries of trafficking implying that the likelihood of a host-source match for trafficking increases for countries that share a common border or are in a common geographical region. This underscores the fact that lower transportation costs play a significant role in explaining the incidence of trafficking between countries. The likelihood to a host-source match for trafficking also increases if a host country is not landlocked --- possibly since countries with sea ports allows traffickers to import victims from a wider spectrum of countries.

As expected, the presence of IDPs/refugees in the source countries increases the likelihood of trafficking in support of the literature that IDPs and refugees are particularly vulnerable to being lured into relocating for employment opportunities, and can subsequently be coerced into illicit activities abroad. Table 4.1 also shows the impact of ethnic fragmentation on the incidence of trafficking under the various conflict measures. Higher ethnic fragmentation increases the likelihood of trafficking from a country while the coefficient on the squared term on ethnic fragmentation is negative and significant under all the conflict measures. This implies that ethnic fragmentation increases the likelihood of trafficking but at a decreasing rate. A possible explanation of this result might be that higher ethnic fragmentation allows middlemen or traffickers to easily target members of different ethnic groups and take advantage of the limited information that potential job seekers have of their credibility. However, as the number of ethnic groups becomes too large, or crosses a critical threshold, middlemen and traffickers may find difficult to operate across different groups if the level of mistrust between members of different ethnic groups rises correspondingly.

As far as our legislative variable is concerned, a ban on prostitution in the source countries of trafficking is associated with a higher likelihood of trafficking. However, it is weakly significant and only for the cumulative intensity, level intensity and count measures of conflict. A possible explanation (and as we discussed earlier) might have to do with a higher reservation price that an illegal market for prostitution bestows on a middleman in the source country in bargaining with a potential buyer in the host country of a trafficked victim. A higher likelihood of trafficking is 
also associated with a source country not being landlocked under our cumulative intensity, level intensity and count measures of conflict. Again existence of sea ports facilitates easier export of trafficked victims from a source country. The rule of law index is negative and significant for source countries but again only for the regression specifications associated with the count and types 1-4 measures of conflict. As one might expect, higher corruption levels and weaker governance structures in poorer countries are likely to lead to these countries becoming origins for trafficked victims.

Turning to the various conflict measures we find that the cumulative intensity, level intensity and count measure of conflict are insignificant predictors of trafficking incidence. However, types 14 measures of conflict are significant, with types 1, 3, 4 reducing while type 2 increasing the incidence of trafficking. Recall that type 1 is extra-state conflict (conflict within a territory with a colonial power and opposition within the colony as adversaries), type 3 is intra-state (between a government and opposition forces with no help from outside governments), type 4 is internationalized intra-state conflict (between a government and opposition forces with help from outside governments for either parties) and type 2 inter-state conflict (between two countries). Thus, types 1, 3 and 4 can be categorized as internal conflicts while type 2 is an external conflict. Our results therefore indicate that internal conflicts reduce the likelihood of trafficking while external conflicts exacerbate the problem. This result, while paradoxical, may be due to the fact that internal conflicts are more likely to disrupt internal transportation networks in a country which impedes the movement of traffickers and potential victims alike.

Table 4.2 reports the results when we use religious fragmentation along with the different measures of conflict to predict the incidence of trafficking. Once again, irrespective of the measure of conflict used, a lower GDP for a source and a higher GDP for the host country leads to higher likelihood of a host-source trafficking match. The presence of IDPs/refugees in the source country, common border, common region, and the host country not being landlocked all positively affect the likelihood of trafficking. Akin to the case of ethnic fragmentation, religious fragmentation in the source country has a positive but decreasing impact on the likelihood of trafficking under all measures of conflict. The rule of law index for source countries is negative and significant for source countries but only for the count and types 1-4 measures of conflict while a ban on prostitution in the source country is positively and significantly related to the likelihood of trafficking for the cumulative intensity, level intensity and count measures of conflict. Finally, internal conflicts (types 1, 3 and 4) decreases, while external conflict (type 2) in a source country increases the likelihood of trafficking. In this respect, the direct impacts of religious fragmentation are very similar to those for ethnic fragmentation.

Lastly, we use the linguistic fragmentation along with the various measures of conflict to see if linguistic fragmentation plays any role in predicting the likelihood of trafficking between countries. As Table 4.3 reports, similar to the case for ethnic and religious fragmentation (and irrespective of the measure of conflict used), a lower GDP for a source and a higher GDP for the host country, presence of IDPs/refugees in the source country, common border, common region and a non-landlocked host all increase the likelihood of a source-host trafficking match. A lower rule of law in the source country has a positive and significant effect on trafficking but only under the count and types 1-4 measure of conflict while a ban on prostitution in the source country increases the likelihood of trafficking under the cumulative intensity, level intensity and 
count measures of conflict. However, the case of ethnic and religious fragmentation, linguistic fragmentation has a positive and significant impact on the likelihood of trafficking only under the count and types 1-4 measures of conflict. Nevertheless, once again internal conflicts (types 1, 3 and 4) decreases, while external conflict (type 2) in a source country increases the likelihood of trafficking.

To summarize, the direct impacts on the incidence of trafficking are (i) lower GDP in source countries, (ii) higher GDP in host countries, (iii) presence of IDPs/refugees in the source country, (iv) common border, (v) common region, (vi) a non-landlocked host country, (vii) a lower rule of law for source countries and (viii) external conflicts in source countries are all positive and significant predictors of a source-host trafficking match irrespective of whether we use ethnic, religious or linguistic measures of fragmentation. Meanwhile, internal conflicts are negative but significant predictors of trafficking under for all three fragmentation indices (ethnic, religious and linguistic). While linguistic fragmentation is positive and significant predictor of trafficking likelihood only under the count and types 1-4 measures of conflict, ethnic and religious fragmentation both increases the likelihood of trafficking under all measures of conflict.

\section{Conclusion}

This paper is a first to explore the nexus between ethnic/religious/fragmentation, different types of conflict, the presence of IDPs and refugees and the incidence of trafficking. Specifically, we relate international trafficking with two separate literatures that studies the link between ethnic/religious fragmentation and conflict on one hand, and the link between conflict and IDPs/refugee other to show that ethnic and religious fragmentation, along with various measures of conflict and the presence of IDPs and refugees in a country are significant predictors of the likelihood of trafficking amongst countries. However, our results in the paper, specially, those that relate to the various measures of conflict are sometimes paradoxical and require further analysis by either regrouping or recoding the various types of conflict that might be overlap with each other, or employing a different estimation strategy to eliminate possible collinearity between the fragmentation, conflict and the IDPs/refugees variables. To partially account for this latter problem we run probit regressions with the IDPs/refugees as a dependant variable and fragmentation, conflict measures and controls for the source countries. The results are reported in the Appendix.

\section{References:}

Akee, Randall, Arnab K. Basu, Arjun Bedi and Nancy H. Chau. (2009); "Combating Trafficking in Women and Children: A Review of International and National Legislation, Co-ordination Failures and Perverse Economic Incentives", The Protection Project Journal of Human Rights and Civil Society, 2, pp 1-24.

Akee, Randall, Arnab K. Basu, Arjun Bedi and Nancy H. Chau. (2010); "Transnational Trafficking, Law Enforcement and Victim Protection: A Middleman's Perspective", mimeo, Department of Applied Economics and Management, Cornell University. 
Alesina, Alberto, Reza Baqir, and William Easterly, (1999); "Public Goods and Ethnic Divisions"; Quarterly Journal of Economics, 114, pp.1243-1284.

Alesina, Alberto, Arnaud Devleeschauwer, William Easterly, Sergio Kurlat and Romain Wacziarg. (2003); "Fractionalization”, Journal of Economics Growth, 8, 155-194.

Bharadwaj, Narad, Shiva K Dhungana, Natalie Hicks, Rebecca Crozier and Charlotte Watson (2007);"Nepal at a Crossroads: The Nexus between Human Security and Renewed Conflict in Rural Nepal"; Friends for Peace and International Alert, Kathmandu, Nepal.

Carling, Jørgen (2005); Trafficking in Women from Nigeria to Europe. Migration Information Source. http://www.migrationinformation.org/Feature/display.cfm?id=318

Castles, Stephen and Sean Loughna (2003); "Trends in Asylum Migration to Industrialized Countries: 1990-2001"; Discussion Paper No. 2003/31, World Institute of Development Research (WIDER), Helsinki.

Central Intelligence Agency (CIA) - The World Factbook (2001); http://www.faqs.org/docs/factbook/index.html

Connor, Walker. (1983); "Beyond Reason: The Nature of the Ethnonational Bond", Ethnic and Racial Studies, 16, pp 373-389.

de Haas, Hein (2006); "International migration and national development: Viewpoints and policy initiatives in countries of origin. The case of Nigeria"; Working papers Migration and Development series, Report 6, International Migration Institute, University of Oxford, UK.

Ehindero, Sola; Obafemi Awolowo and Patience Idemudia (2006); Baseline Study on Forced Labour and Human Trafficking in Kwara, Kano, Cross Rivers and Lagos State in Nigeria. Abuja: ILO/PATWA Offices in Nigeria, Ghana, Sierra Leone and Liberia.

Gleditsch, Nils Petter, Peter Wallensteen, Mikael Eriksson, Margareta Sollenberg and Håvard Strand. (2002); “Armed Conflict 1946-2001: A New Dataset”, Journal of Peace Research 39, pp 615-637.

Global IDP Project (2003); A Global Overview of Internal Displacement. http://www.idpproject.org/global_overview.htm.

Gurr, Ted. (1993); Minorities at Risk: A Global View of Ethnopolitical Conflicts. Washington D.C. United States Institute for Peace.

Horowitz, Donald L., (1985); Ethnic Groups in Conflict, Berkeley, CA: University of California Press.

Ibeanu, Okechukwu. (1999); Exiles in their Own Home: Conflicts and Internal Population Displacement in Nigeria. Journal of Refugees Studies 12(2). 
Kaufmann, Daniel, Aart Kraay and Pablo Zoido-Lobaton. (1999a); “Aggregating Governance Indicators”. World Bank Policy Research Department Working Paper No. 2195.

Kaufmann, Daniel, Aart Kraay and Pablo Zoido-Lobaton. (1999b); "Governance Matters", World Bank Policy Research Department Working Paper No. 2196.

Lee, Chris; Ronny Lindström; Will H. Moore and Kürşad Turan. (2002); "Ethnicity and Repression: The Ethnic Composition of Countries and Human Rights Violations", in Sabine C. Carey and Steven C. Poe (eds.) The Systematic Study of Human Rights.

Lindström, Ronny and Will H. Moore. (1995); "Deprived, Rational or Both? 'Why Minorities Rebel' Revisited,” Journal of Political and Military Sociology, 23, pp 167-190.

Mani, Devyani (2005); “Strengthening Decentralized Governance for Human Security”, United Nations Centre for Regional Development (UNCRD), Nagoya, Japan. http://unpan1.un.org/intradoc/groups/public/documents/UN/UNPAN020337.pdf

Reilly, Benjamin (2000); "Democracy, Ethnic Fragmentation and Internal Conflict: Confused Theories, Faulty Data and the 'crucial case' of Papua New Guinea"; International Security, 25, pp 162-185.

Spiegel, Paul B. (2004); "HIV/AIDS among Conflict-affected and Displaced Populations: Dispelling Myths and Taking Action”, Disasters, 28, pp: 322-339.

Tamang, Ritendra (2009); "Internally Displaced Persons in Nepal: Neglected and Vulnerable"; Asian Social Science, 5, pp 3-11. http://www.ccsenet.org/journal.html

Internal Displacement Monitoring Centre. (2006); Nepal: IDP return still a trickle despite ceasefire.

http://www.internaldisplacement.org/8025708F004BE3B1/(httpInfoFiles)/DDDDE17440C134D7C125720900397F 78/\$file/Nepal\%20overview\%2016oct\%202006.pdf (March 1, 2009)

Protection Project. (2002); Human Rights Report on Trafficking in Persons, Especially Women and Children. School of Advanced International Studies (SAIS), The Johns Hopkins University. Washington, D.C.

UCDP/PRIO. (2009); UCDP/PRIO Armed Conflict Dataset. Version 4-2009.

www.ucdp.uu.se/database, retrieved $1^{\text {st }}$ February 2010.

UNHCR (1995); The State of the World's Refugees: In Search of Solutions. Oxford: Oxford University Press.

UNHCR (2000); The State of the World's Refugees: Fifty Years of Humanitarian Action. Oxford: Oxford University Press. 
UNHCR. (2002); UNHCR Statistical Yearbook 2001. http://www.unhcr.org/4a02e3406.html

UNHCR (2003); 2002 Statistics on Asylum-seekers, Refugees and others of Concern to UNHCR. Geneva.

UNHCR. (2010); Statistical Online Population Database.

http://www.unhcr.org/pages/4a013eb06.html

United Nations Office for the Coordination of Humanitarian Affairs (UNOCHA). (2008); Nepal

Situation Overview.

http://ochaonline.un.org/OchaLinkClick.aspx?link=ocha\&docId=1061738

United States Department of State. (2002); Trafficking in Persons Report. Office of the UnderSecretary for Global Affairs. United States Department of State Publication. World Bank. Various Issues. World Development Indicators. CD-Rom. Washington DC: The World Bank.

Zlotnik, Hania. 1999 "Trends of International Migration since 1965: What Existing Data Reveal", International Migration, 37(1):21-62.

\section{Appendix}

The results related to the measures of conflict (specially, internal ones) are paradoxical at first glance. More often than not, ethnic fragmentation, conflict and IDPs/refugees are highly correlated and while estimating the direct effects, multicollinearity amongst these three variables might well be at play. To partially, account for the collinearity problem we turn to the results from a probit regression below.

refídp $p_{i}=\alpha_{1}+\beta_{1}$ frag $_{i}+\beta_{2}$ frag $_{i}^{2}+\beta_{3}$ Conflict $_{i}+\beta_{4}$ Controls $_{i}+\epsilon_{i}$

In the above equation, the dependent binary dummy variable is now the incidence of refugees and internally displaced at source country level while the explanatory variables are the measures of fragmentation, conflict and controls at the source country level.

We report the regression results for the ethnic, religious and linguistic fragmentation below. Overall our results suggest that there is a relationship between the different fragmentation variables and the presence of refugees and internally displaced persons in our data. We also find evidence that there is some relationship between the presence of refugees or internally displaced persons and other variables of interest. This high level of correlation may explain the relatively large standard errors for certain coefficients in Tables 4.1, 4.2 and 4.3.

Table 5.1 reports the results for ethnic fragmentation. A lower GDP and a lower rule of law index is associated with the presence of IDPs and refugees under all the conflict measures. A ban on prostitution has a positive impact on IDPs and refugees under the count and types 1-4 
measures of conflict while a non-landlocked country has an increased likelihood of the presence of IDPs and refugees under the cumulative intensity and level intensity measures of conflict. Ethnic fragmentation plays a positive but decreasing role under the cumulative and level intensity of conflict but a negative and increasing role under the count and types 1-4 measures of conflict in explaining the presence of IDPs and refugees. Cumulative intensity, level intensity, count and types 3 and 4 (internal conflicts) are positive and significant while types 1 (internal conflict within a colony) and 2 (inter-state conflicts) are negative and significant predictors of the presence of IDPs and refugees in a country.

Next we use religious fragmentation as a predictor of IDPs/refugees along with the different conflict measures and controls for the source countries of trafficking. As Table 5.2 shows religious fragmentation is a positive and significant predictor of the presence of IDPs/refugees in a source country of trafficking for all measures of conflict. A lower GDP, a lower rule of law index as well as legislations banning prostitution positively increase the likelihood of the presence of IDPs and refugees in source countries of trafficking. A non-landlocked country has an increased likelihood of the presence of IDPs and refugees under the cumulative intensity and level intensity measures of conflict but a decreased likelihood under the count measure of conflict. Similar to the case of ethnic fragmentation, cumulative intensity, level intensity, count and types 3 and 4 (internal conflicts) are positive and significant while types 1 (internal conflict within a colony) and 2 (inter-state conflicts) are negative and significant predictors of the presence of IDPs and refugees in a country.

Finally, we find that the results for linguistic fragmentation (Table 5.3) are very similar to those for religious fragmentation above. Linguistic fragmentation is a positive and significant predictor of the presence of IDPs/refugees in a source country of trafficking for all measures of conflict. Similar to the case of ethnic and religious fragmentation, cumulative intensity, level intensity, count and types 3 and 4 (internal conflicts) are positive and significant while types 1 (internal conflict within a colony) and 2 (inter-state conflicts) are negative and significant predictors of the presence of IDPs and refugees in a country. A lower GDP and a lower rule of law index positively increase the likelihood of the presence of IDPs and refugees in source countries of trafficking. A non-landlocked country has an increased likelihood of the presence of IDPs and refugees under the cumulative intensity and level intensity measures of conflict but a decreased likelihood under the count and types 1-4 measures of conflict. Finally a ban on prostitution has a positive influence on the presence of IDPs and refugees only under the count and types 1-4 measures of conflict.

In effect, our results show that ethnic, religious and linguistic fragmentation, along with our various measures of internal conflicts turn out to be strong predictors of the presence of IDPs and refugees. We acknowledge that this may have increased the standard errors in our main regressions of interest which may explain why some coefficients do not achieve statistical significance. 
Table 1: Variable Description

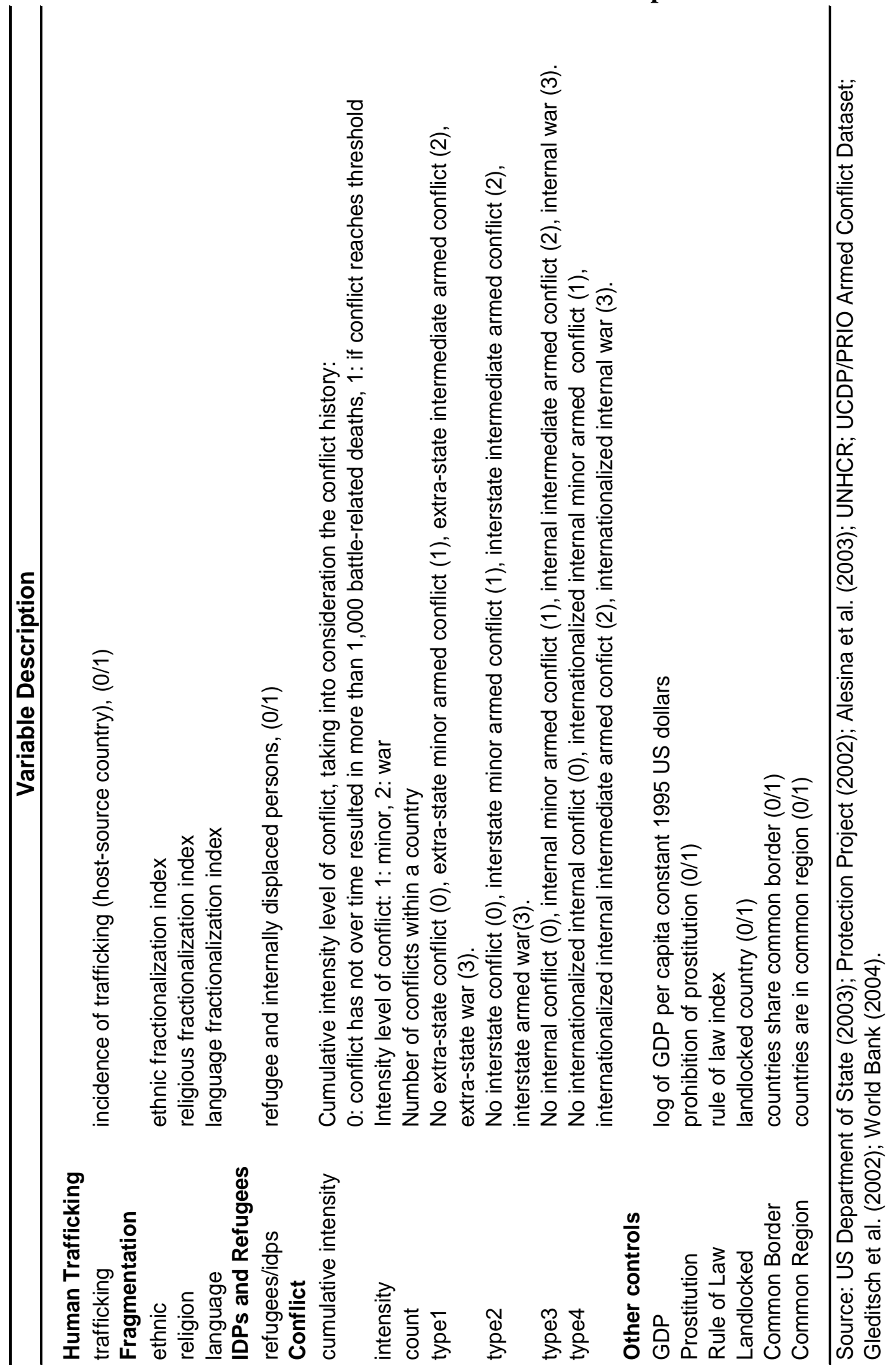


Table 2: Descriptive Statistics: Fragmentation, IDPs/Refugees and Armed Conflict, country level

\begin{tabular}{|c|c|c|c|c|c|}
\hline \multicolumn{6}{|c|}{ Descriptive Statistics: Fragmentation, IDPs/Refugees and Armed Conflict, country level } \\
\hline Variable & Obs. & Mean & Std. Dev. & Min & Max \\
\hline \multicolumn{6}{|l|}{ Fragmentation data } \\
\hline ethnic fractionalization & 180 & 0.440 & 0.255 & 0 & 0.930 \\
\hline religious fractionalization & 177 & 0.391 & 0.277 & 0.002 & 0.923 \\
\hline language fractionalization & 184 & 0.437 & 0.235 & 0.002 & 0.860 \\
\hline \multicolumn{6}{|l|}{ IDPs and Refugees data } \\
\hline IDPs and IDP-like situations (1993-2001 average) & 187 & 25676.09 & 101896.5 & 0 & 875402.9 \\
\hline refugee population by origin (1992-2001 average) & 187 & 63.490 & 259.093 & 0 & 3134.588 \\
\hline IDPs/IDP-like situation and refugees & 187 & 87613.63 & 312417.1 & 0 & 3378246 \\
\hline IDPs/IDP-like situation and refugees dummy & 187 & 0.390 & 0.489 & 0 & 1 \\
\hline \multicolumn{6}{|l|}{ Armed Conflict } \\
\hline \multicolumn{6}{|l|}{ Conflict 1} \\
\hline Intensity level of conflict & 108 & 1.272 & 0.296 & 1 & 2 \\
\hline Cumulative intensity level of conflict & 108 & 0.452 & 0.375 & 0 & 1 \\
\hline \multicolumn{6}{|l|}{ Conflict 2 (1946-2001 average) } \\
\hline Number of conflicts within a country & 187 & 0.257 & 0.471 & 0 & 4.148 \\
\hline Type 1 (extra-state) & 187 & 0.025 & 0.119 & 0 & 0.893 \\
\hline Type 2 (interstate) & 187 & 0.093 & 0.217 & 0 & 1.104 \\
\hline Type 3 (internal) & 187 & 0.206 & 0.415 & 0 & 2.463 \\
\hline Type 4 (internalized internal) & 187 & 0.144 & 0.353 & 0 & 2.259 \\
\hline
\end{tabular}

Table 3: Descriptive Statistics of the estimation sample

\begin{tabular}{lccccc}
\hline \multicolumn{5}{c}{ Descriptive Statistics of the estimation sample } \\
\hline Variable & Obs & Mean & Std. Dev. & Min & Max \\
\hline trafficking & 34969 & 0.017 & 0.130 & 0.000 & 1.000 \\
ethnic & 33660 & 0.440 & 0.254 & 0.000 & 0.930 \\
religion & 34408 & 0.437 & 0.234 & 0.002 & 0.860 \\
language & 33099 & 0.391 & 0.276 & 0.002 & 0.923 \\
refugees/idps & 34969 & 0.390 & 0.488 & 0.000 & 1.000 \\
cumulative intensity & 20196 & 0.452 & 0.373 & 0.000 & 1.000 \\
intensity & 20196 & 1.272 & 0.294 & 1.000 & 2.000 \\
count & 34969 & 0.257 & 0.470 & 0.000 & 4.148 \\
type1 & 34969 & 0.025 & 0.119 & 0.000 & 0.893 \\
type2 & 34969 & 0.093 & 0.216 & 0.000 & 1.104 \\
type3 & 34969 & 0.206 & 0.413 & 0.000 & 2.463 \\
type4 & 34969 & 0.144 & 0.352 & 0.000 & 2.259 \\
GDP source & 31416 & 7.608 & 1.597 & 4.553 & 10.976 \\
GDP host & 31416 & 7.608 & 1.597 & 4.553 & 10.976 \\
Prostitution source & 34221 & 0.383 & 0.486 & 0.000 & 1.000 \\
Prostitution host & 34221 & 0.383 & 0.486 & 0.000 & 1.000 \\
Rule of Law source & 29546 & 0.006 & 0.912 & -2.153 & 1.996 \\
Rule of Law host & 29546 & 0.006 & 0.912 & -2.153 & 1.996 \\
Landlocked source & 33660 & 0.217 & 0.412 & 0.000 & 1.000 \\
Landlocked host & 33660 & 0.217 & 0.412 & 0.000 & 1.000 \\
Common Border & 34969 & 0.015 & 0.120 & 0.000 & 1.000 \\
Common Region & 34969 & 0.154 & 0.361 & 0.000 & 1.000 \\
& & & & & \\
\hline SourceA A & & &
\end{tabular}

Source: Authors' calculations based on US Department of State (2003);

Protection Project (2002); Alesina et al. (2003); UNHCR; UCDP/PRIO Armed Conflict Dataset;

Gleditsch et al. (2002); World Bank (2004). 
Table 4.1: Direct Impact, Marginal Effects, Ethnic Fractionalization Probit Regressions: Direct Impact

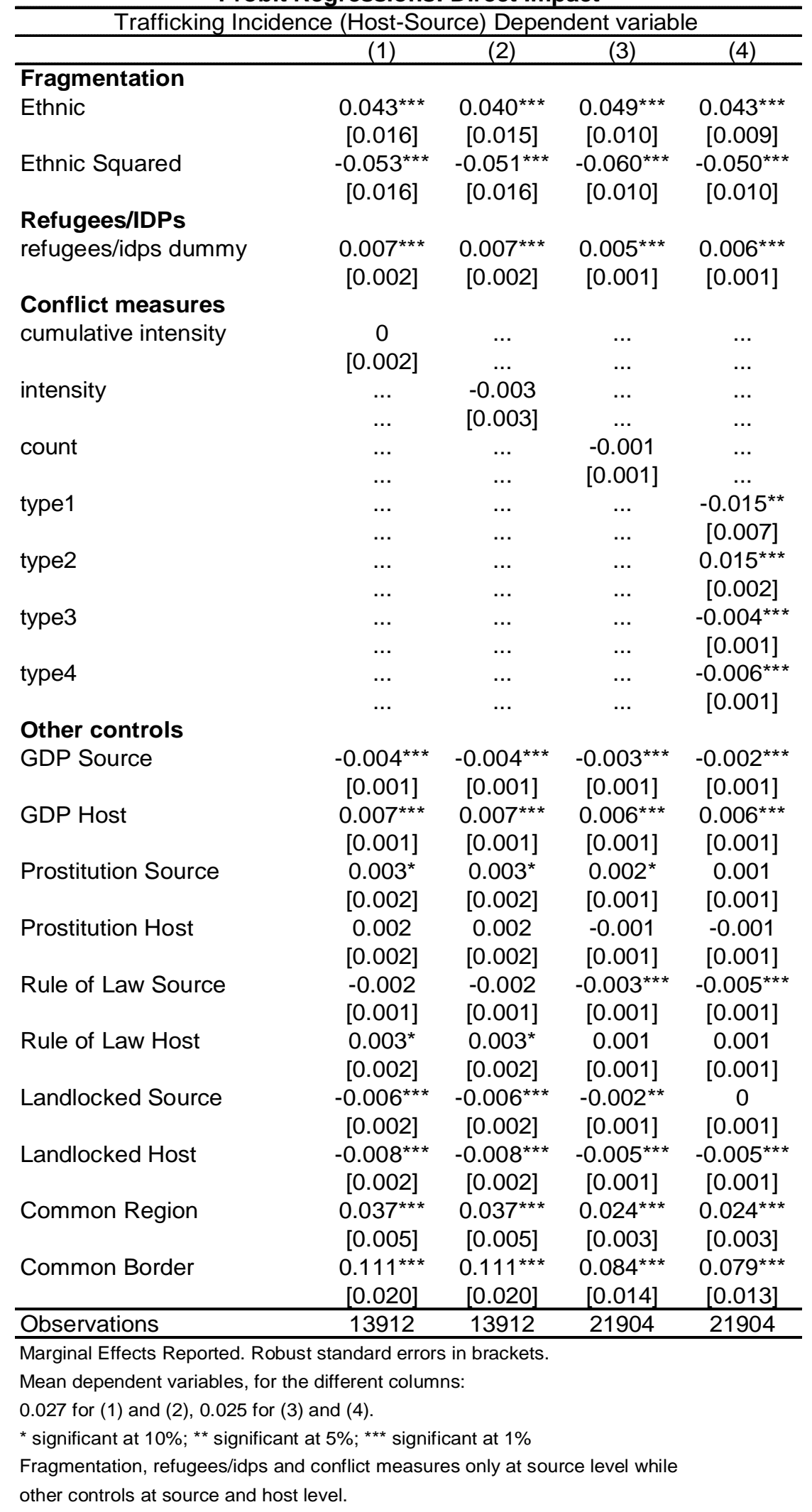


Table 4.2: Direct Impact, Marginal Effects, Religious Fractionalization Probit Regressions: Direct Impact

\begin{tabular}{|c|c|c|c|c|}
\hline \multicolumn{5}{|c|}{ Trafficking Incidence (Host-Source) Dependent variable } \\
\hline & $(1)$ & $(2)$ & (3) & $(4)$ \\
\hline \multicolumn{5}{|l|}{ Fragmentation } \\
\hline Religion & $\begin{array}{c}0.059^{\star \star *} \\
{[0.013]}\end{array}$ & $\begin{array}{c}0.060^{\star \star *} \\
{[0.013]}\end{array}$ & $\begin{array}{c}0.055^{\star * *} \\
{[0.010]}\end{array}$ & $\begin{array}{c}0.045^{\star * *} \\
{[0.010]}\end{array}$ \\
\hline Religion Squared & $\begin{array}{c}-0.073^{\star * \star} \\
{[0.016]}\end{array}$ & $\begin{array}{c}-0.074^{* * *} \\
{[0.016]}\end{array}$ & $\begin{array}{c}-0.062^{\star * *} \\
{[0.011]}\end{array}$ & $\begin{array}{c}-0.048^{\star \star \star *} \\
{[0.011]}\end{array}$ \\
\hline \multicolumn{5}{|l|}{ Refugees/IDPs } \\
\hline refugees/idps dummy & $\begin{array}{c}0.008^{\star * *} \\
{[0.002]}\end{array}$ & $\begin{array}{c}0.008^{* * *} \\
{[0.002]}\end{array}$ & $\begin{array}{c}0.005^{* * *} \\
{[0.001]}\end{array}$ & $\begin{array}{c}0.005^{\star * *} \\
{[0.001]}\end{array}$ \\
\hline \multicolumn{5}{|l|}{ Conflict measures } \\
\hline cumulative intensity & $\begin{array}{c}-0.002 \\
{[0.002]}\end{array}$ & $\begin{array}{l}\ldots \\
\ldots\end{array}$ & $\begin{array}{l}\ldots \\
\ldots\end{array}$ & $\begin{array}{l}\ldots \\
\ldots\end{array}$ \\
\hline intensity & $\begin{array}{l}\ldots \\
\ldots\end{array}$ & $\begin{array}{l}-0.005^{\star} \\
{[0.003]}\end{array}$ & $\begin{array}{l}\ldots \\
\ldots\end{array}$ & $\begin{array}{l}\ldots \\
\ldots\end{array}$ \\
\hline count & $\begin{array}{l}\ldots \\
\cdots\end{array}$ & $\begin{array}{l}\ldots \\
\ldots\end{array}$ & $\begin{array}{c}-0.001 \\
{[0.002]}\end{array}$ & $\ldots$ \\
\hline type1 & $\begin{array}{l}\ldots \\
\ldots\end{array}$ & $\begin{array}{l}\ldots \\
\ldots\end{array}$ & $\begin{array}{l}\ldots \\
\ldots\end{array}$ & $\begin{array}{c}-0.020^{\star * *} \\
{[0.007]}\end{array}$ \\
\hline type2 & $\begin{array}{l}\ldots \\
\ldots\end{array}$ & $\ldots$ & $\begin{array}{l}\ldots \\
\cdots \\
\ldots\end{array}$ & $\begin{array}{c}0.016^{\star \star \star} \\
{[0.002]}\end{array}$ \\
\hline type3 & $\begin{array}{l}\ldots \\
\ldots\end{array}$ & $\begin{array}{l}\ldots \\
\ldots\end{array}$ & $\begin{array}{l}\cdots \\
\ldots\end{array}$ & $\begin{array}{c}-0.003^{\star *} \\
{[0.001]}\end{array}$ \\
\hline type4 & $\begin{array}{l}\ldots \\
\ldots\end{array}$ & $\begin{array}{l}\cdots \\
\ldots\end{array}$ & $\begin{array}{l}\cdots \\
\ldots\end{array}$ & $\begin{array}{c}-0.007^{\star \star \star *} \\
{[0.001]}\end{array}$ \\
\hline \multicolumn{5}{|l|}{ Other controls } \\
\hline GDP Source & $\begin{array}{c}-0.003^{\star * *} \\
{[0.001]}\end{array}$ & $\begin{array}{c}-0.003^{* * *} \\
{[0.001]}\end{array}$ & $\begin{array}{c}-0.003^{\star * *} \\
{[0.001]}\end{array}$ & $\begin{array}{c}-0.002^{* * *} \\
{[0.001]}\end{array}$ \\
\hline GDP Host & $\begin{array}{l}0.007^{\star * *} \\
{[0.001]}\end{array}$ & $\begin{array}{c}0.007^{* * *} \\
{[0.001]}\end{array}$ & $\begin{array}{c}0.007^{* * *} \\
{[0.001]}\end{array}$ & $\begin{array}{c}0.006^{\star * *} \\
{[0.001]}\end{array}$ \\
\hline Prostitution Source & $\begin{array}{c}0.005^{\star \star \star} \\
{[0.002]}\end{array}$ & $\begin{array}{c}0.005^{\star \star \star} \\
{[0.002]}\end{array}$ & $\begin{array}{c}0.004^{\star \star *} \\
{[0.001]}\end{array}$ & $\begin{array}{l}0.002^{\star \star} \\
{[0.001]}\end{array}$ \\
\hline Prostitution Host & $\begin{array}{c}0.002 \\
{[0.002]}\end{array}$ & $\begin{array}{c}0.002 \\
{[0.002]}\end{array}$ & $\begin{array}{l}-0.001 \\
{[0.001]}\end{array}$ & $\begin{array}{l}-0.001 \\
{[0.001]}\end{array}$ \\
\hline Rule of Law Source & $\begin{array}{l}-0.001 \\
{[0.001]}\end{array}$ & $\begin{array}{c}-0.001 \\
{[0.001]}\end{array}$ & $\begin{array}{c}-0.003^{\star \star \star} \\
{[0.001]}\end{array}$ & $\begin{array}{c}-0.006^{\star \star *} \\
{[0.001]}\end{array}$ \\
\hline Rule of Law Host & $\begin{array}{c}0.003^{*} \\
{[0.002]}\end{array}$ & $\begin{array}{l}0.003^{*} \\
{[0.002]}\end{array}$ & $\begin{array}{c}0 \\
{[0.001]}\end{array}$ & $\begin{array}{c}0 \\
{[0.001]}\end{array}$ \\
\hline Landlocked Source & $\begin{array}{c}-0.005^{\star \star \star} \\
{[0.002]}\end{array}$ & $\begin{array}{c}-0.005^{\star \star \star} \\
{[0.002]}\end{array}$ & $\begin{array}{c}-0.002 \\
{[0.001]}\end{array}$ & $\begin{array}{c}0.001 \\
{[0.001]}\end{array}$ \\
\hline Landlocked Host & $\begin{array}{c}-0.008^{\star \star *} \\
{[0.002]}\end{array}$ & $\begin{array}{c}-0.008^{\star * *} \\
{[0.002]}\end{array}$ & $\begin{array}{c}-0.006^{* * *} \\
{[0.001]}\end{array}$ & $\begin{array}{c}-0.005^{\star * *} \\
{[0.001]}\end{array}$ \\
\hline Common Region & $\begin{array}{l}0.036^{\star * *} \\
{[0.005]}\end{array}$ & $\begin{array}{c}0.036^{* * *} \\
{[0.005]}\end{array}$ & $\begin{array}{c}0.024^{* * *} \\
{[0.003]}\end{array}$ & $\begin{array}{c}0.024^{* * *} \\
{[0.003]}\end{array}$ \\
\hline Common Border & $\begin{array}{l}0.111^{* * *} \\
{[0.020]}\end{array}$ & $\begin{array}{c}0.111^{* * *} \\
{[0.020]}\end{array}$ & $\begin{array}{c}0.086^{\star * *} \\
{[0.014]}\end{array}$ & $\begin{array}{c}0.080^{* * *} \\
{[0.013]}\end{array}$ \\
\hline Observations & 14060 & 14060 & 22052 & 22052 \\
\hline \multicolumn{5}{|c|}{ Marginal Effects Reported. Robust standard errors in brackets. } \\
\hline \multicolumn{5}{|c|}{ Mean dependent variables, for the different columns: } \\
\hline \multicolumn{5}{|c|}{0.027 for (1) and (2), 0.024 for (3) and (4). } \\
\hline $\begin{array}{l}\text { Fragmentation, refugees/idps } \\
\text { other controls at source and h }\end{array}$ & onflict measure & es only at so & & \\
\hline
\end{tabular}


Table 4.3: Direct Impact, Marginal Effects, Language Fractionalization Probit Regressions: Direct Impact

\begin{tabular}{|c|c|c|c|c|}
\hline \multicolumn{5}{|c|}{ Trafficking Incidence (Host-Source) Dependent variable } \\
\hline & (1) & (2) & (3) & (4) \\
\hline \multicolumn{5}{|l|}{ Fragmentation } \\
\hline \multirow[t]{2}{*}{ Language } & 0.005 & 0.003 & $0.019^{\star *}$ & $0.014^{*}$ \\
\hline & [0.012] & [0.012] & [0.008] & {$[0.007]$} \\
\hline \multirow{2}{*}{ Language Squared } & -0.009 & -0.008 & $-0.024^{\star \star \star}$ & $-0.017^{* *}$ \\
\hline & [0.013] & [0.013] & [0.009] & [0.008] \\
\hline \multicolumn{5}{|l|}{ Refugees/IDPs } \\
\hline refugees/idps dummy & $\begin{array}{c}0.010^{* * *} \\
{[0.002]}\end{array}$ & $\begin{array}{c}0.010^{* * *} \\
{[0.002]}\end{array}$ & $\begin{array}{c}0.007^{* * *} \\
{[0.002]}\end{array}$ & $\begin{array}{c}0.007^{\star * *} \\
{[0.001]}\end{array}$ \\
\hline \multicolumn{5}{|l|}{ Conflict measures } \\
\hline cumulative intensity & $\begin{array}{c}-0.001 \\
{[0.002]}\end{array}$ & $\begin{array}{l}\ldots \\
\ldots\end{array}$ & $\begin{array}{l}\ldots \\
\ldots\end{array}$ & $\begin{array}{l}\cdots \\
\ldots\end{array}$ \\
\hline \multirow[t]{2}{*}{ intensity } & $\ldots$ & -0.005 & $\cdots$ & ... \\
\hline & $\ldots$ & [0.003] & $\cdots$ & $\ldots$ \\
\hline \multirow[t]{2}{*}{ count } & $\cdots$ & $\ldots$ & -0.001 & $\ldots$ \\
\hline & $\ldots$ & $\ldots$ & [0.002] & \\
\hline \multirow[t]{2}{*}{ type1 } & $\ldots$ & $\ldots$ & $\cdots$ & $-0.021^{\star \star \star}$ \\
\hline & $\cdots$ & $\cdots$ & $\cdots$ & [0.007] \\
\hline \multirow{2}{*}{ type2 } & $\cdots$ & $\cdots$ & .. & $0.016^{\star \star *}$ \\
\hline & $\cdots$ & $\cdots$ & $\cdots$ & [0.002] \\
\hline \multirow{2}{*}{ type3 } & $\cdots$ & $\cdots$ & $\cdots$ & $-0.003^{\star \star}$ \\
\hline & $\cdots$ & $\cdots$ & $\cdots$ & [0.001] \\
\hline type4 & $\cdots$ & $\cdots$ & $\cdots$ & $-0.007^{* \star *}$ \\
\hline \multicolumn{5}{|l|}{ Other controls } \\
\hline GDP Source & $\begin{array}{c}-0.003^{* * *} \\
{[0.001]}\end{array}$ & $\begin{array}{c}-0.003^{\star * *} \\
{[0.001]}\end{array}$ & $\begin{array}{c}-0.003^{* * *} \\
{[0.001]}\end{array}$ & $\begin{array}{c}-0.002^{* * *} \\
{[0.001]}\end{array}$ \\
\hline GDP Host & $\begin{array}{c}0.007^{* * *} \\
{[0.001]}\end{array}$ & $\begin{array}{c}0.007^{* * *} \\
{[0.001]}\end{array}$ & $\begin{array}{c}0.007^{* * *} \\
{[0.001]}\end{array}$ & $\begin{array}{c}0.006^{* * *} \\
{[0.001]}\end{array}$ \\
\hline Prostitution Source & $\begin{array}{l}0.004^{\star *} \\
{[0.002]}\end{array}$ & $\begin{array}{l}0.004^{* *} \\
{[0.002]}\end{array}$ & $\begin{array}{l}0.003^{* *} \\
{[0.001]}\end{array}$ & $\begin{array}{c}0.001 \\
{[0.001]}\end{array}$ \\
\hline Prostitution Host & $\begin{array}{c}0.002 \\
{[0.002]}\end{array}$ & $\begin{array}{c}0.002 \\
{[0.002]}\end{array}$ & $\begin{array}{l}-0.001 \\
{[0.001]}\end{array}$ & $\begin{array}{c}-0.001 \\
{[0.001]}\end{array}$ \\
\hline Rule of Law Source & $\begin{array}{l}-0.002 \\
{[0.002]}\end{array}$ & $\begin{array}{l}-0.002 \\
{[0.002]}\end{array}$ & $\begin{array}{c}-0.004^{* * *} \\
{[0.001]}\end{array}$ & $\begin{array}{c}-0.006^{* * *} \\
{[0.001]}\end{array}$ \\
\hline Rule of Law Host & $\begin{array}{c}0.003^{*} \\
{[0.002]}\end{array}$ & $\begin{array}{l}0.003^{*} \\
{[0.002]}\end{array}$ & $\begin{array}{c}0 \\
{[0.001]}\end{array}$ & $\begin{array}{c}0 \\
{[0.001]}\end{array}$ \\
\hline Landlocked Source & $\begin{array}{c}-0.004^{\star *} \\
{[0.002]}\end{array}$ & $\begin{array}{l}-0.004^{\star} \\
{[0.002]}\end{array}$ & $\begin{array}{c}-0.001 \\
{[0.001]}\end{array}$ & $\begin{array}{c}0.001 \\
{[0.001]}\end{array}$ \\
\hline Landlocked Host & $\begin{array}{c}-0.008^{\star \star \star} \\
{[0.002]}\end{array}$ & $\begin{array}{c}-0.008^{\star \star *} \\
{[0.002]}\end{array}$ & $\begin{array}{c}-0.006^{\star \star \star} \\
{[0.001]}\end{array}$ & $\begin{array}{c}-0.005^{\star \star \star} \\
{[0.001]}\end{array}$ \\
\hline Common Region & $\begin{array}{c}0.038^{\star \star *} \\
{[0.005]}\end{array}$ & $\begin{array}{c}0.038^{\star \star *} \\
{[0.005]}\end{array}$ & $\begin{array}{c}0.025^{\star * *} \\
{[0.003]}\end{array}$ & $\begin{array}{c}0.024^{* * *} \\
{[0.003]}\end{array}$ \\
\hline Common Border & $\begin{array}{l}0.107^{* * *} \\
{[0.020]}\end{array}$ & $\begin{array}{c}0.107^{* * *} \\
{[0.020]}\end{array}$ & $\begin{array}{c}0.083^{* * *} \\
{[0.014]}\end{array}$ & $\begin{array}{c}0.077^{* * *} \\
{[0.013]}\end{array}$ \\
\hline Observations & 13616 & 13616 & 21460 & 21460 \\
\hline \multicolumn{5}{|c|}{ Marginal Effects Reported. Robust standard errors in brackets. } \\
\hline \multicolumn{5}{|c|}{ Mean dependent variables, for the different columns: } \\
\hline 0.028 for (1) and (2), $0.025 \mathrm{f}$ & nd (4). & & & \\
\hline * significant at $10 \%$; * sign & $5 \% ;{ }^{* * *}$ signi & nt at $1 \%$ & & \\
\hline Fragmentation, refugees/idp & fflict measu & only at so & Evel while & \\
\hline
\end{tabular}


Table 5.1: Probit Regressions, Marginal Effects, Ethnic Fractionalization Probit Regressions

\begin{tabular}{|c|c|c|c|c|}
\hline \multicolumn{5}{|c|}{ Refugees/IDPs Dummy Dependent Variable } \\
\hline & $(1)$ & $(2)$ & (3) & $(4)$ \\
\hline \multicolumn{5}{|l|}{ Fragmentation } \\
\hline Ethnic & $\begin{array}{c}0.660^{* * *} \\
{[0.075]}\end{array}$ & $\begin{array}{c}0.701^{* * *} \\
{[0.076]}\end{array}$ & $\begin{array}{c}-0.477^{\star * *} \\
{[0.056]}\end{array}$ & $\begin{array}{c}-0.891^{\star * *} \\
{[0.058]}\end{array}$ \\
\hline Ethnic Squared & $\begin{array}{c}-1.077^{\star \star *} \\
{[0.078]}\end{array}$ & $\begin{array}{c}-1.092^{* * *} \\
{[0.079]}\end{array}$ & $\begin{array}{c}0.032 \\
{[0.059]}\end{array}$ & $\begin{array}{c}0.464^{\star * *} \\
{[0.061]}\end{array}$ \\
\hline \multicolumn{5}{|l|}{ Conflict measures } \\
\hline cumulative intensity & $\begin{array}{c}0.368^{\star \star \star} \\
{[0.011]}\end{array}$ & $\begin{array}{l}\cdots \\
\ldots\end{array}$ & $\begin{array}{l}\cdots \\
\ldots\end{array}$ & $\begin{array}{l}\cdots \\
\ldots\end{array}$ \\
\hline intensity & $\begin{array}{l}\cdots \\
\ldots\end{array}$ & $\begin{array}{c}0.378^{\star * *} \\
{[0.016]}\end{array}$ & $\begin{array}{l}\cdots \\
\ldots\end{array}$ & $\begin{array}{l}\cdots \\
\ldots\end{array}$ \\
\hline count & $\begin{array}{l}\cdots \\
\ldots\end{array}$ & $\begin{array}{l}\cdots \\
\ldots\end{array}$ & $\begin{array}{c}0.601^{\star * *} \\
{[0.010]}\end{array}$ & $\begin{array}{l}\cdots \\
\ldots\end{array}$ \\
\hline type1 & & $\begin{array}{l}\ldots \\
\ldots\end{array}$ & $\begin{array}{l}\ldots \\
\ldots\end{array}$ & $\begin{array}{c}-0.401^{* * *} \\
{[0.028]}\end{array}$ \\
\hline type2 & $\ldots$ & $\ldots$ & $\ldots$ & $-0.138^{\star * *}$ \\
\hline type3 & $\begin{array}{l}\cdots \\
\ldots \\
\ldots\end{array}$ & $\begin{array}{l}\cdots \\
\ldots \\
\ldots\end{array}$ & $\begin{array}{l}\cdots \\
\cdots \\
\ldots\end{array}$ & $\begin{array}{c}0.510^{* * *} \\
{[0.013]}\end{array}$ \\
\hline type4 & $\ldots$ & $\ldots$ & $\begin{array}{l}\ldots \\
\ldots\end{array}$ & $\begin{array}{c}0.446^{* * *} \\
{[0.012]}\end{array}$ \\
\hline Other controls & & & & \\
\hline GDP & $\begin{array}{c}-0.172^{\star * *} \\
{[0.005]}\end{array}$ & $\begin{array}{c}-0.170^{* * *} \\
{[0.005]}\end{array}$ & $\begin{array}{c}-0.162^{* * *} \\
{[0.004]}\end{array}$ & $\begin{array}{c}-0.153^{\star * *} \\
{[0.004]}\end{array}$ \\
\hline Prostitution & $\begin{array}{l}0.016^{*} \\
{[0.008]}\end{array}$ & $\begin{array}{c}0.007 \\
{[0.008]}\end{array}$ & $\begin{array}{c}0.111^{\star * *} \\
{[0.007]}\end{array}$ & $\begin{array}{c}0.137^{\star * *} \\
{[0.007]}\end{array}$ \\
\hline Rule of Law & $\begin{array}{c}-0.170^{* * *} \\
{[0.008]}\end{array}$ & $\begin{array}{c}-0.194^{\star * *} \\
{[0.008]}\end{array}$ & $\begin{array}{c}-0.196^{* * *} \\
{[0.007]}\end{array}$ & $\begin{array}{c}-0.155^{\star * *} \\
{[0.007]}\end{array}$ \\
\hline Landlocked & $\begin{array}{c}-0.114^{* * *} \\
{[0.012]}\end{array}$ & $\begin{array}{c}-0.097^{* * *} \\
{[0.012]}\end{array}$ & $\begin{array}{c}0.004 \\
{[0.010]}\end{array}$ & $\begin{array}{c}-0.011 \\
{[0.010]}\end{array}$ \\
\hline Observations & 17484 & 17484 & 27528 & 27528 \\
\hline
\end{tabular}

Marginal Effects Reported. Robust standard errors in brackets.

Mean dependent variables, for the different columns:

0.585 for (1) and (2), 0.426 for (3) and (4).

* significant at $10 \%$; ${ }^{* *}$ significant at $5 \%$; ${ }^{* * *}$ significant at $1 \%$

Only Source country side. 
Table 5.2: Probit Regressions, Marginal Effects, Religious Fractionalization Probit Regressions

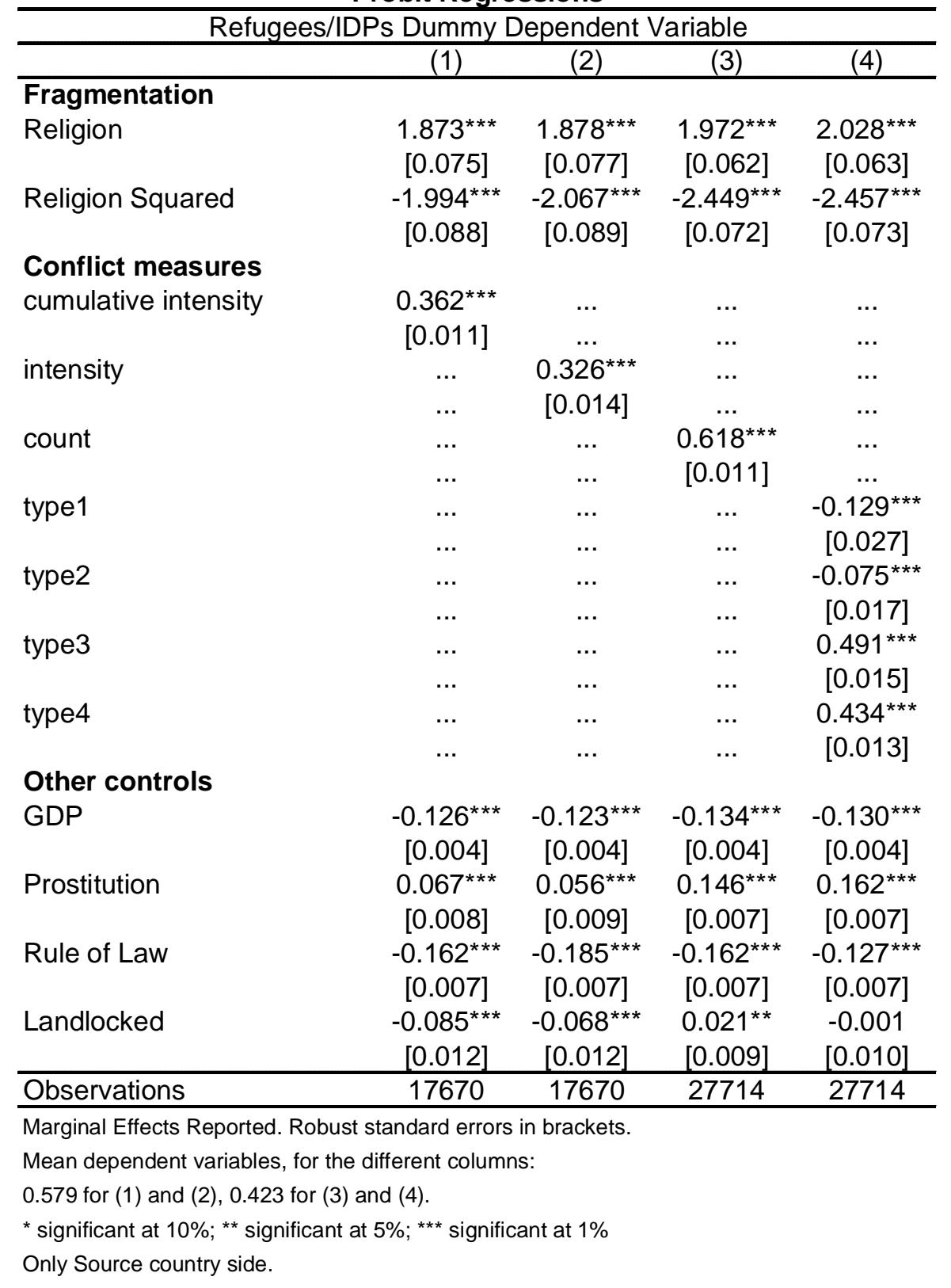


Table 5.3: Probit Regressions, Marginal Effects, Language Fractionalization Probit Regressions

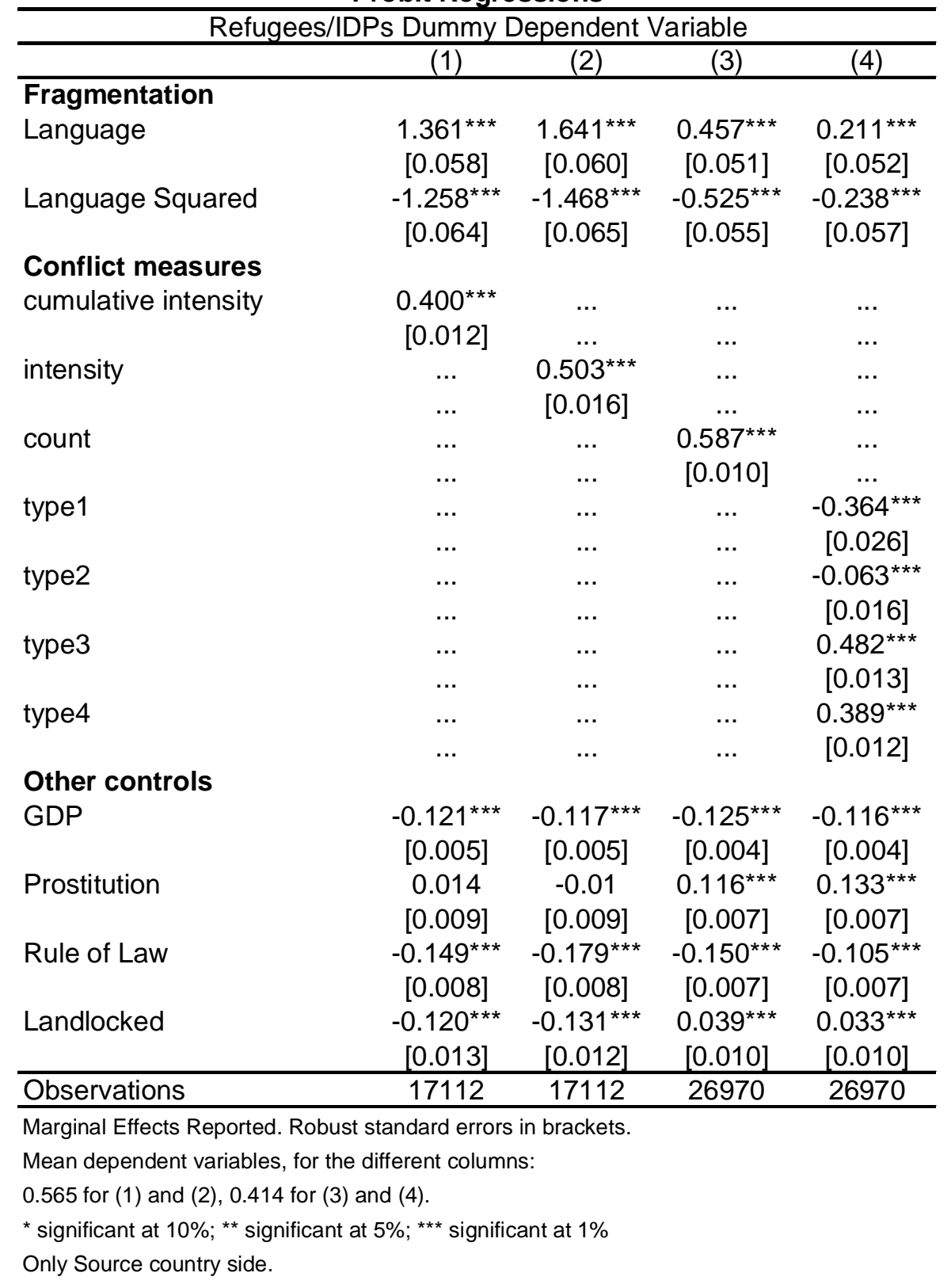

